\title{
Geometry Skill Analysis In Problem Solving Reviewed From The Difference Of Cognitive Style Students Junior High School
}

\author{
Andi Saparuddin Nur ${ }^{1}$, Evy Nurvitasari ${ }^{2}$ \\ ${ }^{1}$ Musamus University \\ Email: andisaparuddin@unmus.ac.id \\ ${ }^{2}$ Musamus University \\ Email: evy.nurvitasari@gmail.com
}

(Received: October-2017; Reviewed: November-2017; Accepted: November-2017; Published: December-2017)

(C)2017 -EST Graduate Program Universitas Negeri Makassar. This is an article with open access under license CC BY-NC-4.0 (https://creativecommons.org/licenses/by-nc/4.0/ ).

\begin{abstract}
This study aimed to analyze the geometry skills in solving problems in terms of cognitive styles differences in the students of SMP Negeri Urumb. The type of this research is descriptive research that is qualitative with case study approach. The subject of this research is all students of SMP Negeri Urumb. Subject selection is done by using snowball sampling technique. The main instrument in this study is the researchers themselves and accompanied by supporting instruments such as diagnostic tests, geometry solving test, and interview guides. Validity and reliability of data is done through credibility test, transferability test, dependability test, and confirmability test. Data analysis consists of data collection, data reduction, data presentation, and conclusions. The results of this study were (1) reflective FI subjects showing visual, verbal, drawing, and logic skills with level of geometry thinking at level 2 (informal deduction); (2) impulsive FI subjects exhibiting visual, verbal, and drawing skills with geometric thinking level at level 1 (analysis), (3) reflective FD subjects exhibit visual skills, and draw with level of geometric thinking at level 0 (visualization), and (4) impulsive FD subjects exhibit visual, verbal skills with geometric level thinking at level 0 (visualization).
\end{abstract}

Keywords : geometry skill; problem solving; cognitive style.

\section{INTRODUCTION}

Problem solving is an important aspect of mathematics learning. NCTM (2000) mentions that problem solving is an important component that must be mastered by students in learning mathematics. In line with this, Permendiknas (2006) listed problem solving skills as a learning objective of mathematics at junior high school level (SMP). However, some studies indicate that the problem solving ability of junior high school students in Indonesia is still low (Balitbang Depdiknas, 2007; Tjalla, 2010). Of some materials taught in junior high, geometry is one of the most difficult material for students to understand (Tjalla, 2010).

Understanding the concept of geometry is strongly supported by the perception of students both visually and spatially. Learning geometry in junior high school requires an approach that involves internal factors of students, including cognitive style. Based on the observations obtained through daily document examination of the value of daily test in SMP Negeri Urumb, there are facts that show $80 \%$ of students have not understood the concept of geometry well. Students are still severely impeded in the process of visualization and abstraction of the concept of geometry and are only capable of performing arithmetic operations involving the basic formulas in determining the area and circumference of the flat wake. In addition, students' perceptions have not been well connected when viewed from the learning process and the material taught through school

Conventional learning through lecture methods using school textbooks has not assisted students in learning geometric concepts. This is due to the characteristics of students in the SMP Negeri Urumb unique unique views of the way 
of thinking and culture that shape it. The concept of geometry is very familiar in Marind tribe society which is the original entity of students of SMP Negeri Urumb. Marind community culture that implements the concept of geometry can be seen through the instrument Tifa which is a representation of one form of conic sliced with a geometric shape in the form of carving. If it is associated with the context of learning in schools, should the culture that forms the students of SMP Negeri Urumb does not hamper his geometric skills.

Cognitive style is one aspect related to the student's personal and has a close relationship with the success of students in learning (Winkel, 2012). In line with that, Basey (Purnomo, 2015: 110) reveals that cognitive style is a control process or style that is selfmanagement, as a situational intermediary to determine the conscious activity so that students use to organize and organize, receive and disseminate information and ultimately determine behavior. Meanwhile, Kagan (Warli, 2010) mentions cognitive style is an individual variation in how to feel, remember, and think or as a way of differentiating, understanding, storing, manifesting, and utilizing information.

Broadly speaking cognitive style can be distinguished psychologically, conceptually tempo, and the process of thinking (Rahman, 2008). Cognitive style differences are psychological, including: cognitive style field dependent (FD) and field independent (FI). The cognitive style differences are conceptually tempo, including: reflective and impulsive cognitive styles whereas cognitive style differences based on thought processes are distinguished over intuitive-inductive and logicdeductive cognitive styles. The process of skill in geometry involves more cognitive styles based on psychological and conceptual factors of tempo (Purnomo, 2015; Rahmatina, 2014; Effendi, 2011). Therefore, this study focuses on geometric skills in terms of cognitive style differences both psychologically and conceptually tempo.

Geometry is one field of study in mathematics that involves the concept of waking flat and building space as the object of study. According to Battista (Van de Walle, 2013: 402) geometry is a concept of reasoning network and a reperesentation system used to explore and analyze shapes and spaces. Musser (2008: 582) mentions that the concept and nature of geometry is an important component in the basic mathematics curriculum that has a wealth of concepts, problem-solving experience, and application.

The process of learning geometry at the elementary and secondary levels can not be separated from the Van Hiele theory. Musser (2008) mentions that Van Hiele's theory relates to the level of thought processes of students in doing the reasoning level of holistic thinking, analysis, to the stage of abstract mathematical deduction. The level of geometric thinking according to Van Hiele consists of five stages with each stage is a prerequisite for rising to the higher stage of thinking (Musser, 2008). The geometric thinking level according to Van Hiele's theory is described in Table 1.

Learning geometry at the junior level when associated with Van Hiele's theory then the students' thinking level is mostly at the level of 0-2 (Van de Walle, 2013). This is due to the ability to think at the age of students in junior high school is mostly in the transition stage is, the concrete operation phase of thinking to the formal thinking stage. Students are not yet mature cognitively to conduct more formal thinking operations by developing a deductive axiom. Therefore, the geometry skills that can be demonstrated by the students also vary depending on the level of thinking.

The level of geometric thinking has relevance to the student's ability to demonstrate geometric skills (Muhassanah, 2014: 57). Geometry skills is one of the means by which students can solve geometry problems. According to Hoffer (Muhassanah, 2014: 55) geometry skill consists of 5 (five) types, namely: 1. Visual skills are the ability to identify geometric structures based on observations that can be seen directly.

2. Verbal skills include the ability to define a form based on characteristics or attributes attached to the form.

3. Drawing skills is the ability to abstract a form based on the nature, characteristics, and characteristics it possesses.

4. Logical skills are the ability to understand the principles of conservation of geometric shapes and are capable of spatial reasoning.

5. Applied skills include the ability to connect the concept of an object geometry and develop a given model to solve the problem. 
Table 1. Classification of Thinking Geometry Levels According to Van Hiele Theory

\begin{tabular}{|c|c|}
\hline Level of Thinking & Charasteristics \\
\hline $\begin{array}{l}\text { Level } 0 \\
\text { (visualisation) }\end{array}$ & $\begin{array}{l}\text { Able to think of visible and observable forms. } \\
\text { - }\end{array}$ \\
\hline $\begin{array}{l}\text { Level } 1 \\
\text { (Analysis) }\end{array}$ & $\begin{array}{l}\text { - Able to explain the general nature of an object. } \\
\text { - Be able to generalize objects based on their } \\
\text { characteristics. }\end{array}$ \\
\hline $\begin{array}{l}\text { Level } 2 \\
\text { (Informal Deduction) }\end{array}$ & $\begin{array}{l}\text { Be able to classify various objects based on the } \\
\text { relationship between the properties it has. } \\
\text { - Able to make logical reasoning informally. } \\
\text { - } \\
\text { Able to submit hypotheses (assumptions) about } \\
\text { various properties of the form. }\end{array}$ \\
\hline $\begin{array}{l}\text { Level } 3 \\
\text { (Deduction) }\end{array}$ & $\begin{array}{l}\text { - Able to analyze the relationship between nature and } \\
\text { geometric objects. } \\
\text { - Able to build a list of axioms and definitions for the } \\
\text { theorem. } \\
\text { - }\end{array}$ \\
\hline $\begin{array}{l}\text { Level } 4 \\
\text { (Rigor) }\end{array}$ & $\begin{array}{l}\text { - Able to think of a thorough axiomatic deduction } \\
\text { system rather than bits and pieces. } \\
\text { - Able to connect a series of different axioms and } \\
\text { theorems }\end{array}$ \\
\hline
\end{tabular}

Source: Van de Walle (2013)

Based on the above description, the purpose of this research is to analyze and explore the students' geometry skills in solving problems in terms of cognitive style differences. As for the question of this research is, "how is the geometry skill in solving the problem in terms of students' cognitive style differences?"

\section{METHOD}

The type of this research is descriptive research that is qualitative with case study approach. This research was conducted at SMP Negeri Urumb located in Kampung Urumb, Semangga District, Merauke District. This study was conducted from May to July 2017.

Subjects in this study were all students of SMP Negeri Urumb. The selection of research subjects was done by using snowball sampling technique. Prior to the subject selection process, researchers used a diagnostic test, Group Embedded Figure Test (GEFT) to obtain subjects based on psychological cognitive style categories and Matching Familiar Figure Test (MFFT) to obtain subjects based on tempo conceptual cognitive style categories. Category of cognitive style on GEFT tests according to Witkin (Ibrahim, 2004) cognitive-field- dependent students if the correct answer is $\leq 9$, and field independent if the correct answer $\geq 9$. Meanwhile, in MFFT tests, Warli (Rahmatina, 2014: 65) categorizes students as reflective cognitive-style subjects if the time required $(t) \geq$ 7 minutes 30 seconds and the number of questions answered correctly (f) $\geq 7$ questions, whereas students are categorized as the subject of impulsive cognitive style if the time required (t) $\leq 7$ minutes 30 seconds and the number of questions answered correctly (f) $\leq 7$ questions.

Instruments in this study are divided into two types, namely: (1) Key instruments and (2) Supporting instruments. Key instruments in this study are the researchers themselves who play a major role and must be neutral and objective in exposing information. Meanwhile, the supporting instrument in this research is diagnostic test, that is; GEFT tests, and MFFT tests, as well as problem-solving tests with semistructured interview guidelines. Data collection techniques in this study using test and non-test techniques. The test technique in this research is used to collect categorization data of research subjects by using GEFT test and MFFT test and the students' geometry skill test data in solving the problem. Non-test technique in this research is used to collect data in the form of information 
process of students' geometry skill in solving problems through semi structured interview.

Validity and reliability of data include 4 (four) testing phase, namely; credibility test, transferability test, dependability test, and confirmability test (Ary et al, 2010). Data analysis in this research is done at the time of data collecting takes place, and after completion of data collection in certain period. Activity in data analysis, divided into four (4) stages, namely; data collection, data reduction, data presentation, and data verification.

\section{RESULTS}

GEFT and MFFT diagnostic test results, obtained by cognitive-style FD, FI, impulsive, and reflective cognitive categories. In order to obtain a problem-based geometry skill data on the subject under study, the next data collection process is performed by selecting at least one subject for each impulsive FD category, reflective FD, impulsive FI, and reflective FI. Each subject was given a problem-based question for analyzing geometry skills and geometric thinking level. The question is symbolized by P: a tube of unknown diameter and a height of 2: 5 . If the base area is $314 \mathrm{~cm}^{2}$, then determine the volume and area of the webs!

Testing of data credibility is done by using technique triangulation technique, that is by confirming result of subject answer by semi structured interview. In order to obtain reliable data and ensure that the subject answer does not change then also made the triangulation of time. The results showed that after a different time span, the subject of the study gave a relatively similar solution so that the data was credible to be analyzed.

\section{Geometry Skills Analysis On Reflective FI Subjects}

The ability to understand the problem on the reflective FI subject begins with finding the elements that need to be known to plan for problem solving. The reflective FI subject thinks that the element needed to solve the problem is not explicitly known in the problem, but rather needs to relate it to the concept of the tube. Therefore, the reflective FI subject has the idea of connecting the area of the tube base with the circle so as to obtain a long picture of the tube radius in question. The reflective FI subject is able to describe the tube well as well as to understand the interrelation of the elements of space wake in determining its volume.
Understanding the subject of a reflective FI is not affected by the limitations of information on the problem although the radius and height of the tube are known only in the form of a comparison.

In the problem-solving phase, the reflective FI subject identifies each known element to be applied in problem solving. The reflective FI subject is able to think that there are two different problems to be solved, namely the volume and extent of the tubular nets. The reflective FI subject is able to communicate well to the problem-solving process using illustrative images. The reflective FI subject explains well the broad meaning of the tubular webs and applies them to problem solving.

The problem-solving process shown by the reflective FI subject involves visual, verbal, drawing, and logic skills. The reflective FI subject is able to identify the elements on the tube and express it in sentence form. Understanding of the concept of space on the tube is further illustrated in the form of drawings, so that description is made the main step in solving the problem. Reflective FI subjects are able to use visualization, and spatial reasoning to allow for a process of thinking about the conservation of geometric shapes. The geometric skill demonstrated by reflective FI subjects is at level 2 (informal deduction) that is capable of logical reasoning classifies the element of the forming tube in solving the problem.

\section{Geometry Skills Analysis On Impulsive FI Subjects}

The subject of the impulsive FI understands the problem by mentioning known and questioned elements intuitively. The impulsive FI subject assumes all the information needed in solving the problem has been explicitly written on the matter. According to the impulsive FI subject, the information on the question has been sufficient to plan the problem solving by knowing the high ratio and the radius of the tube without making a deep thought process about the meaning of the comparison.

In the problem solving planning process, the impulsive FI subject describes the tube by means of the drawing, then determining the radius of the circle by using the base of the known base on the problem. The subject of impulsive FI understands that the base on the tube is a circle. After obtaining the length of the 
radius of the circle, the impulsive FI subject determines the height of the tube through a known ratio to the problem. It shows that the impulsive FI subject is able to find the information needed.

The impulsive FI subject determines the volume of the tube by multiplying the base area and the height of the tube. However, the calculation process is done in a hurry without any effort to re-examine the results obtained. The width of the tube nets resolved the subject of the FI impulsively intuitively and ignored the area of the tube blanket. The impulsive FI subject does not have a conservation profile of the forms of the tubular nets so that only the shape of the base and the circular tube cover can be considered. Nevertheless, the impulsive FI subject is able to provide a well-defined description of the tube based on the elements it possesses. The geometric skills that the impulsive FI subject to in problem solving are visual, verbal, and drawing skills with a level of geometric thinking at level 1 (analysis) that is able to explain the general nature of an object.

\section{Geometry Skills Analysis On Reflective FD Subjects}

The process of understanding the problem on the reflective FD subject is directly fixed on the ratio of diameter and height of the tube. The subject of reflective FD is influenced by a question form that involves the concept of comparison resulting in a focus on determining which elements should be known in planning for problem solving. The subject of the reflective FD tries to understand the problem by drawing the tube as well as illustrating the meanings of the comparisons contained in the problem. However, the thinking process is not systematic and depends heavily on the procedural understanding associated with the formula. The reflective FD subject assumes that the area of the tube is the necessary element in determining the volume of the tube. The dependence of the reflective FD subject on procedural ability in determining tube width results in the interpretation that the tube represents half of the sphere. This is an indication that the reflective FD subject is not able to communicate the elements that the tube has in solving the problem.

The problem-solving process done by the reflective FD subject depends heavily on his knowledge of the concept of the ball. According to the reflective FD subject, the tube and the ball have a relationship so that in solving the problem it is necessary to know the area of the sphere first. The subject of the reflective FD is not well understood, the tube-forming elements are circles and blankets which, when stretched on a flat, rectangular plane. A solution capable of a reflective FD subject only by trying to recall a concept associated with a tube without analyzing the similarities and differences in properties that the concept possesses. Geometric skills that reflective FD subjects can demonstrate are visual skills, and draw with a level of geometric thinking at level 0 (visualization) that is able to think of a form that can be observed and characterize the object.

\section{Analysis of Geometry Skills on Impulsive FD Subjects}

The subject of the impulsive FD understands the problem intuitively by using the same concept of comparison as in the line segment concept. Subject impulsive FD does not understand the meaning of the comparison contained in the problem so that the process of problem-solving planning directly focused on efforts to obtain the value of radius and height of the tube. The subject of impulsive FD does not first describe the problem into the picture but directly determine the diameter of the tube by using the comparison contained in the problem. The subject of the impulsive FD hastily determines the diameter of the tube regardless of the broad meaning of the tube base. The impulsive FD subject has a problem-solving plan by determining the tube diameter value. Furthermore, the subject of the impulse FD writes the difference between the known value of the ratio and the multiplying by the base area to determine the diameter of the tube. The subject of the impulsive FD does not engage in an in-depth thinking process so that the process undertaken at the beginning of problem-solving planning quickly changes at a later stage.

The impulsive FD subject is mistaken in writing the tube volume formula because the comparisons contained in the problem are not well understood. The subject of the impulse FD assumes the comparison on the problem is the diameter and height of the tube so that the sought is diameter. Assuming the value that has been obtained is the diameter, the subject impulsive FD adds a $1 / 2$ coefficient on the tube 
formula. Furthermore, the subject of impulsive FD has not yet understood the relationship between radius and diameter resulting in a false conclusion. The intuitive thinking process is still very dominant subjected to impulsive FD subjects at the planning and problem-solving stage.

The subject of the impulsive FD determines the extent of the tubular nets by describing the constituent elements of the tube. The subject of the impulsive FD is able to construct a flat tube builder appropriately, but it is still mistaken in the application of the wideweb formulas. Intuitively, the subject of the impulse FD determines the extent of the tubular nets by summing the squares of the radius of the tube by the area of two circles. The subject of the impulsive FD assumes the area of a square tube-shaped blanket with a side-length size equal to the radius of the tube-bottom circle. This suggests that the subject of the impulsive FD draws conclusions only on the assumption that the tube blanket shuffles the tubular base in the shape of a circle and uses the radius of the circle as the side of the tube blanket. The geometric skills that the impulsive FD subject imparts are visual, verbal skills with a level of geometric thinking at level 0 (visualization).

\section{DISCUSSION}

Cognitive style has a role in processing information and analyze a problem. The results showed that the reflective and impulsive FI subjects were more able to analyze the problem systematically and coherently and identify the elements needed in solving the problem. The subject of reflective or impulsive FD is relatively hasty in solving the problem and relies heavily on procedural concepts that ignore the analytic thinking process and involves more intuitive thought processes. This is in line with the opinion of Effendi (2011) which mentions FI students are better able to analyze a problem without being influenced by external factors compared with FD students.

The geometric skills that the entire subject is able to show are at the level of geometry level 0 (visualization) to level 2 (informal deduction). This is in line with the results of research Muhassanah (2014) which mentions the ability to think geometry of junior high school students are between levels 0-2.
Furthermore, the type of geometry skills that the FI subjects exhibit more with higher thinking processes than the subject of FD. If we look at the conceptual cognitive style of tempo then the reflective subject takes a longer time to explore the problem and to re-examine every step taken. Unlike the case with impulsive subjects that use a shorter time by assuming every step is done right. This is in line with the opinion of Warli (2010) which mentions the reflective subject to re-examine every step of the problem solving than impulsive subjects who tend to think intuitively.

\section{CONCLUSIONS AND SUGGESTIONS}

Based on the results of the study and discussion, it can be concluded that the reflective FI subjects exhibit visual, verbal, drawing, and logical skills with a level of geometric thinking at level 2 (informal deduction), impulsive FI subjects exhibiting visual, verbal, and drawing skills with geometric thinking level 1 (analysis), reflective FD subject shows visual skills, and draws with a level of geometric thinking at level 0 (visualization), as well as impulsive FD subjects showing visual skills, and drawing with a level of geometric thinking at level 0 (visualization). The advice in this research is that students are given the opportunity to develop their geometry skills. In addition, there needs to be further research related to the development of geometry material that involves geometry skills in problem solving. It is also hoped that the next researcher can focus students' geometric skills on the conceptual tempo cognitive style is fast accurate, and slow inaccurate.

\section{ACKNOWLEDGEMENT}

This research is funded by Dikti DRPM through the Beginners Lecturer Research Scheme Year 2017 Number: 052.15 / UN52.8 / LT / 2017.

\section{REFERENCE}

Ary,D. Jacob, L.C. Sorensen, C. Razavieh, A. (2010). Introduction to Research in Education Eight Edition. Belmont: Cengage Learning. 
Balitbang Depdiknas. (2007). Ringkasan Studi PISA. Jakarta: Depdiknas.

Effendi, A. Sjarkawi. Asrial. (2011). Pengaruh Interaksi Media dan Gaya Kognitif Terhadap Penguasaan Konsep Bangun Datar dan Bangun Ruang. Jurnal Tekno-Pedagogi. Volume 1, No. 2. Hal 15-26.

Ibrahim, M., Zainuddin., Johari., \& Winnie. (2004). Relationship between cognitive styles, level of cognitive thinking and chemistry achievement among form four science students. Johor bahru: Universiti Teknologi Malaysia.

Muhassanah, N. Sujadi, I. Riyadi. (2014). Analisis Keterampilan Geometri Siswa Dalam Memecahkan Masalah Geometri Berdasarkan Tingkat Berpikir Van Hiele. Jurnal Elektronik Pembelajaran Matematika. Volume 2, No. 1. Hal 5466.

Musser, G. Burger, W. Peterson, B. (2008). Mathematics For Elementary Teacher: A Contemporary Approach Eight Edition. New York: John Wiley \& Sons, Inc.

NCTM. (2000). Principles and Standards for School Mathematics. Reston VA: The National Council of Teacher Mathematics Inc.

Permendiknas No.22. (2006). Standar Isi untuk Satuan Pendidikan Dasar dan Menengah. Jakarta: Kemdiknas.

Purnomo, D.J. Asikin, M. Junaedi, I. (2015). Tingkat Berpikir Kreatif Pada Geometri Siswa Kelas VII Ditinjau dari Gaya Kognitif dalam Setting Problem Based Learning. Unnes Journal of Mathematics Education. Volume 4, No. 2. Hal 109-115.

Rahman, A. (2008). Analisis Hasil Belajar Matematika Berdasarkan Perbedaan Gaya Kognitif Secara Psikologis dan Konseptual Tempo Pada Siswa Kelas X SMA Negeri 3 Makassar. Jurnal Pendidikan dan Kebudayaan. Volume 14, No.2. hal 452-473.

Rahmatina, S. Sumarmo, U. Johar, R. (2014). Tingkat Berpikir Kreatif Siswa dalam Menyelesaikan Masalah Matematika Berdasarkan Gaya Kognitif Reflektif dan Impulsif. Jurnal Didaktik
Matematika. Volume 1, No.1. Hal 6270.

Tjalla, A. (2010). Potret Mutu Pendidikan Indonesia Ditinjau dari Hasil-Hasil Studi Internasional. Makalah dipresentasikan dalam seminar temu ilmiah nasional guru II Universitas Terbuka. Jakarta, 23 November 2010.

Warli. (2010). Profil Kreativitas Siswa yang Bergaya Kognitif Reflektif dan Siswa yang Bergaya Kognitif Impulsif dalam Memecahkan Masalah Geometri. Disertasi tidak dipubliskasikan. Surabaya: Program Pascasarjana Universitas Negeri Surabaya.

Winkel, WS. (2012). Psikologi Pengajaran. Yogyakarta: Media Abadi.

Van De Walle. (2013). Elementary and Middle School Mathematics Teaching and Developmentally Eight Edition. New Jersey: Pearson Education. 